DOI: https://doi.org/10.26661/hst-2019-2-79-09

\title{
FACTORS FOR THE PREPARATION OF HIGH MASTER ATHLETES IN THE CONTEXT OF SPORTS ORGANIZATION STAFF COMPETENCES
}

\author{
(C) ŠARŪNAS, BIČIUŠAS \\ E-mail: s.biciusas@gmail.com, ORCID iD: https://orcid.org/0000-0003-0368-2417 \\ Lithuanian Sports University (Kaunas, Lithuania) \\ Lietuvos sporto universitetas Sporto 6 Каунасский уезд, 44221 Kaunas, Lithuania
}

\begin{abstract}
It is important for sports organizations not only to retain existing athletes, to attract new ones, but also to be able to reveal their professionalism and help them to achieve good results. Achieving athlete performance is important in sports organization personnel management, which includes many componentsю This study raises the following problematic question - what needs to be changed (improved) in the personnel management of sports organizations in order to increase the performance of athletes? The scientific literature more extensively examines the peculiarities of sports organization management) [5] and the significance of this management improvement for service quality) [6] the influence of personnel management professionalism on sports organizations performance [8, 3, 9]. Organizational performance [7,4], impact of institutional change on the activities of sports organizations [2, 3], importance of electronic sport in organizational management [4], influence of gender differences on sports organizations in management [1], The aim of the research - to determine the directions of improvement of sports organization personnel management by examining the content of sports organization personnel management and the role of employees in the development of athletic performance. The tasks of the research: to analyze the role of sports organization staff in athlete education; to examine the factors of athletic performance development; determine the specifics and content of sports organization personnel management for the purpose of athlete performance; to identify directions of improvement of sports organization personnel management in order to increase the performance of athletes. The following research methods are used for the purpose of the research aim: analysis and synthesis of scientific literature, quantitative questionnaire survey and methods statistic analyze. SPSS and Microsoft Excel software were used for processing, systematizing and graphical representation of the research data. Conclusions. According to the majority of respondents, the most important factors for athletes' performance are: a high quality environment for sports facilities; qualified and motivated staff to train athletes; individual employee dedication. However, many respondents value on average the motivation of staff to develop athletes and the quality of the environment in their sports facilities. Respondents most appreciate the following professional activities of coaches: knowledge of their sport; athlete support; goal setting for sports; providing coach-athlete educational interaction; creating an environment and motivational climate. The results of the coaches 'professional and personal qualities showed that most of the respondents rated the coaches' strong character and dedication to work, and on average, their ability to organize activities and confidence in athletes. It appears that many respondents are in favor of matching the didactic and subject competencies required by coaches to train high performance athletes.

During the research, the directions of improvement of sports organization personnel management in order to increase the performance of athletes were determined, which are
\end{abstract}

Factors for the preparation of high master athletes in the context of sports organization staff competences 
related both to the functions of the coaches, their competence and the personnel management of the sports organization.

Keywords: sports organizations, personnel management, competencies, athletes.

\section{INTRODUCTION}

Relevance of the work. The role of sports organization staff is significant in the process of training athletes. In a sports organization, personnel management is concerned with ensuring an efficient workforce, the sporting achievements of the users of sports services, and promoting the sports organization.

Strategic personnel management planning within a sports organization influences the quality of services provided, helps to predict how to respond to the ever-increasing demand for consumer sports services, what to expect, and what to do in future staff planning and athletic performance. It is important that the training of athletes is coherent with the strategy of the whole sports organization [6]. The key factors in athlete performance development are related not only to the quality of the athletic facilities, the cost of services, qualified staff, but also to the coach's positive communication with the athletes.

The Law on Sports of the Republic of Lithuania emphasizes that a coach is a "highly skilled sports specialist who prepares an athlete (athletes) for highly skilled sports competitions and / or guides an athlete (s) for these sports competitions". The professional preparation of the coach to train athletes and the personal qualities of the coach greatly influence the performance of the athlete. In Zilinskiene's (2008) opinion, significant trainer qualities that contribute to athlete's performance are good knowledge of their sport; ability to be the initiator of sporting activities; ability to develop harmonious relationships with trainees; ability to perform practices well, promote tolerance and patience; ability to motivate and promote; ability to develop psychological stability, self-confidence. S. Sterkowicz et al. (2007) state that a coach must be able to motivate athletes, while at the same time playing a variety of roles: being both a teacher, an observer and a manager.

The trainer should motivate the athletes to achieve results through professionalism, ability to organize activities, personal qualities such as: solid character, dedication, patience, insight, professionalism and so on. In their activities, the trainer applies his or her knowledge guided by the mission, goals of the sports organization in which he or she works. He / she must be motivated to improve his / her competences, be able to apply innovative educational methods, take into account the individual characteristics of the athletes, their abilities, athletic achievements and needs [22, 26]. Sabaliauskas (2017) states that a coach preparing high-performance athletes should have both didactic, subject- specific, personal, research and professional mentoring competences.

According to Sabaliauskas (2017), a trainer should be able to make flexible decisions, be dedicated to 
work, look at everything with optimism, but be able to ensure discipline, order and be self-confident. All this can ensure successful training management and good athletic performance. In addition, it is believed that "the coach's knowledge, erudition, and available sporting experience - membership of a national team and participation in international competitions - are considered important factors for confidence in the coach's competence" [21]. The quality of a coach's work depends on the knowledge of the athlete's individuality, his or her ability to awaken inherent powers, to help unfold. It is important to know not only the athlete's health, physical condition, empathize with the states, thoughts, but also to correctly understand the goals set for himself and to identify the motivating factors [1].

S. Sterkowicz et al. (2007) showed in their research that athletes' performance is influenced by both psychological communication factors and physical fitness. A great importance is played on planning of the training process itself, which focuses on positive communication with athletes. Other factors that contribute to high athletic performance include: coach's education; athlete's psychological and tactical fitness, physique, physical endurance, motivation; control of opponents' tactics; the conditions established by the organization for the rest of the athlete and the recovery of his / her strength; pedagogical work organized by the coach [24].
Motivation is encouraged through coach's communication with the athlete. According to Taylor (2009), an athlete must be motivated to maximize their physical abilities and achieve their goals, and be prepared to work hard when they feel tired, boredom, pain, and are anxious to do other things. According to Lebezdinsk et al. (2016), communication with athletes helps create positive emotions, foster relationships, and create a training-friendly environment. Communication and sharing of thoughts, feelings and advice contribute to the development of a full-fledged athlete's motivation, initiative, desire to win, and encourage determination. Petronel and Florentina (2013) argue that communication determines interaction with the athlete, trust.

It is important for the coach to create conditions for comprehensive physical, mental and social education, developing a value-based approach to sport and health, to this end, to contribute to the creation of a supportive and empowering environment and to be able to impart knowledge. Coakley (2011) emphasizes the importance of promoting positive social interaction in order to get to know athletes and their needs, expectations about sports performance and a supportive coaching climate.

Coaches have a strong influence on athletes' actions, beliefs and can foster healthy competition [17]. Camire (2015) also states that it is expedient to create an appropriate training environment that is equipped

Factors for the preparation of high master athletes in the context of sports organization staff competences 
with the right equipment, safe (appropriate equipment, sports equipment, proper maintenance), and organize educational activities of interest. Training environment must be safe not only physically but also psychologically encouragement, empathy).

The aim of the research - to determine the directions of improvement of sports organization personnel management by examining the content of sports organization personnel management and the role of employees in the development of athletic performance. The tasks of the research: to analyze the role of sports organization staff in athlete education; to examine the factors of athletic performance development; determine the specifics and content of sports organization personnel management for the purpose of athlete performance; to identify directions of improvement of sports organization personnel management in order to increase the performance of athletes. The following research methods are used for the purpose of the research aim: analysis and synthesis of scientific literature, quantitative questionnaire survey and methods of statistic analysis. SPSS and Microsoft Excel software were used for processing, systematizing and graphical representation of the research data. A quantitative survey was conducted and a questionnaire survey was used. The sample of the survey was 98 respondents (the recipients of services of sports organizations - athletes). The sample was calculated using Paniotto's formula [30]. Where $\mathrm{n}$ is the sample size; $\Delta$ - magnitude of error $(0,05) ; \mathrm{N}$ - size of the general population):

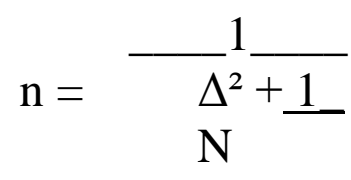

The survey focused on the participation of older athletes aged 16 and over who can already register and sign contracts with foreign clubs. The sampling method is non-probabilistic convenience sampling. It included "those units of the general population are related to the professional activity of the author of the work itself. The questionnaire (written) method was chosen for the research. A research instrument - a questionnaire - has been created for this purpose (see Table 1). that are easily accessible" [19], i.e.,

Table 1. Justification of the research instrument

\begin{tabular}{|c|c|}
\hline The structural parts of the questionnaire & $\begin{array}{c}\text { Prepared on the basis of the } \\
\text { authors }\end{array}$ \\
\hline Elements specific to a sports organization & Dilys, 2015; Siegfrieda et al., 2015 \\
\hline Factors of athletic performance development & $\begin{array}{l}\text { Petronel, Florentina, 2013; } \\
\text { Strazdiene, Adaskeviciene, } \\
\text { Mikalauskas et al., } 2015\end{array}$ \\
\hline Elements of a sports organization personnel management system & Juodeikaite, Fominiene, 2016 \\
\hline Functions and roles of coaches' professional activities & Sabaliauskas, 2017; Zilinskiene, 2008 \\
\hline
\end{tabular}




\begin{tabular}{|l|l|}
\hline Professional and personal qualities of coaches & Miskinis, 2008; Zilinskiene, 2008 \\
\hline $\begin{array}{l}\text { The need for coaching competences in training high performance } \\
\text { athletes }\end{array}$ & Sabaliauskas, 2017 \\
\hline
\end{tabular}

The survey was conducted by placing a questionnaire on the survey site https://www.manoapklausa.lt. The link to the questionnaire was sent to the participating organizations and circulated through social networks and their groups. Leaders of organizations and coaches invited athletes to attend. Questionnaire link was sent to athletes in person, too.

The research was conducted anonymously. The basic ethical principles of scientific research were followed [27]: respect for the privacy of the person, confidentiality, attitude to do no harm for the researched person, justice. The aim was to ensure the voluntary participation of athletes in the survey. They were not constrained, participated voluntarily, and it was sought to ensure equality for all respondents.

\section{THE RESULTS AND DISCUSSION}

In order to achieve the aim of the research, respondents' perceptions of various sports organization-specific activities were explored. Fig. 1, summarized data, shows that the respondents favor the achievement of high athlete results (good $38.8 \%$; very good $12.2 \%$ ) and involvement in the sports market (31.6 \%, $11.2 \%$; respectively) purposeful implementation of the functionality of a sports organization through a team of staff $(33.7 \% ; 8.2 \%)$, achieving goals $(29.6 \%$; $20.4 \%$;

On average, many respondents value attracting new athletes (44.9 percent) and retaining existing athletes $(40.8 \%)$. The majority rated the financial resources available (attracted) and the involvement of sponsors as poor (14.3\%; very poor $11.2 \%)$.

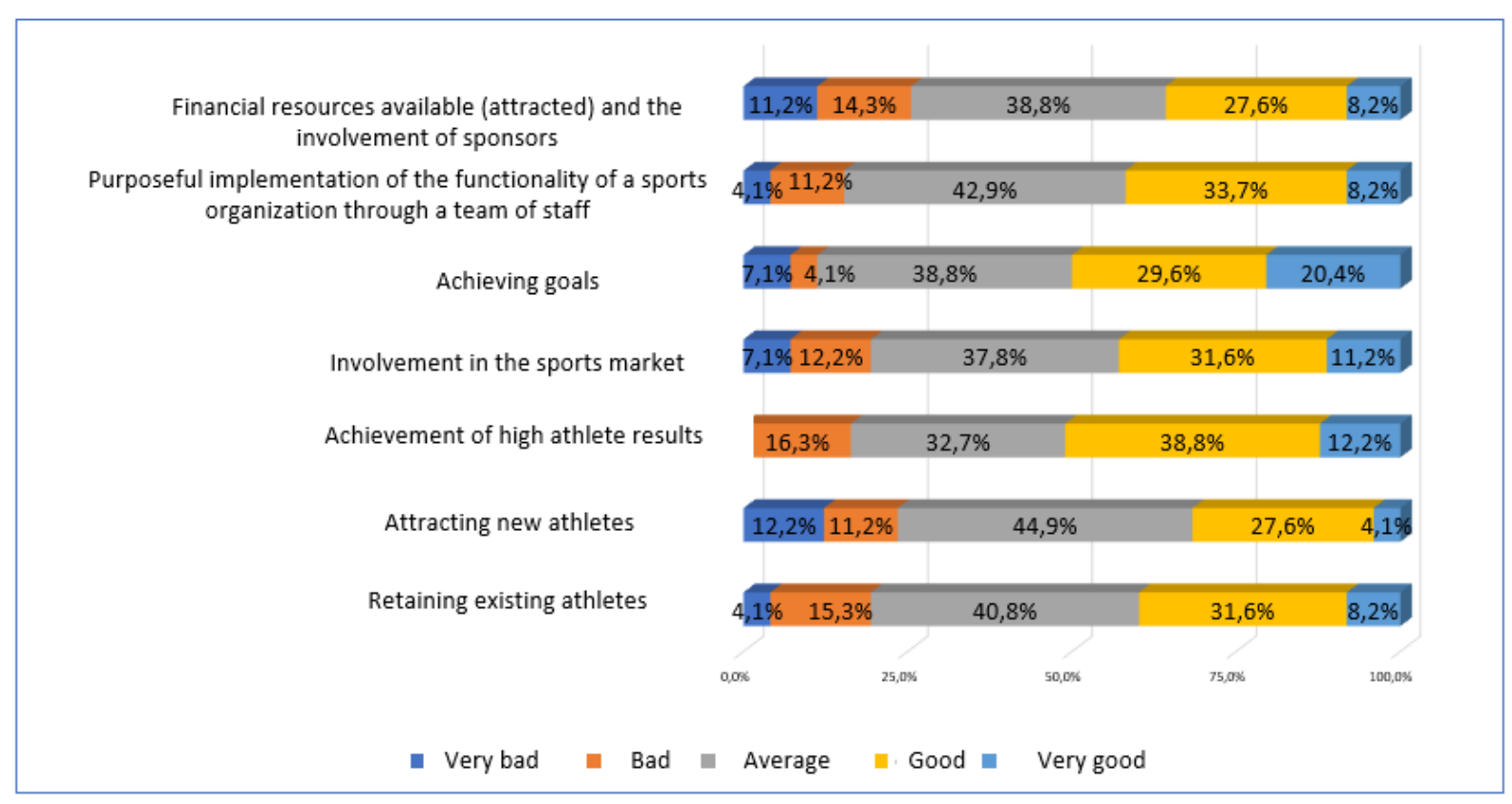

Factors for the preparation of high master athletes in the context of sports organization staff competences 
Figure 1. Evaluation of various sports organization specific activities

However, many respondents value on average the motivation of staff to develop athletes and the quality of the environment in their sports facilities. Not all are satisfied with observing and responding to changes in athletes' well-being, accepting an athlete as an equal partner, and individual dedication of staff. The majority of respondents believe that the performance of athletes depends mainly on their job satisfaction, training opportunities and reward. During the research, the directions of the development of the personnel management of the sports organization were established in order to increase the performance of the athletes, both in relation to the functions of the coaches, their competence and the personnel management of the sports organization. The research aimed to determine the factors of athletic performance development (see Figure 2). According to the statements of many respondents, it is seen that the most important factors of athletes' performance are: high quality environment of sports bases (very important - 46.9\%; important $53.1 \%)$, motivated staff to train athletes (respectively 69.4\%; 30.6 $\%$ ), qualified staff $(58.2 \% ; 37.8 \%)$; individual employee dedication (58.2\%; 37.8\%). Respondents' attitude towards the importance of responding to athlete preferences differed: one-third (30.6\%) think it is very important, just as much $(30.6 \%)$ think it is partially important, and over one-third $(38.8 \%)$ think that it is important.

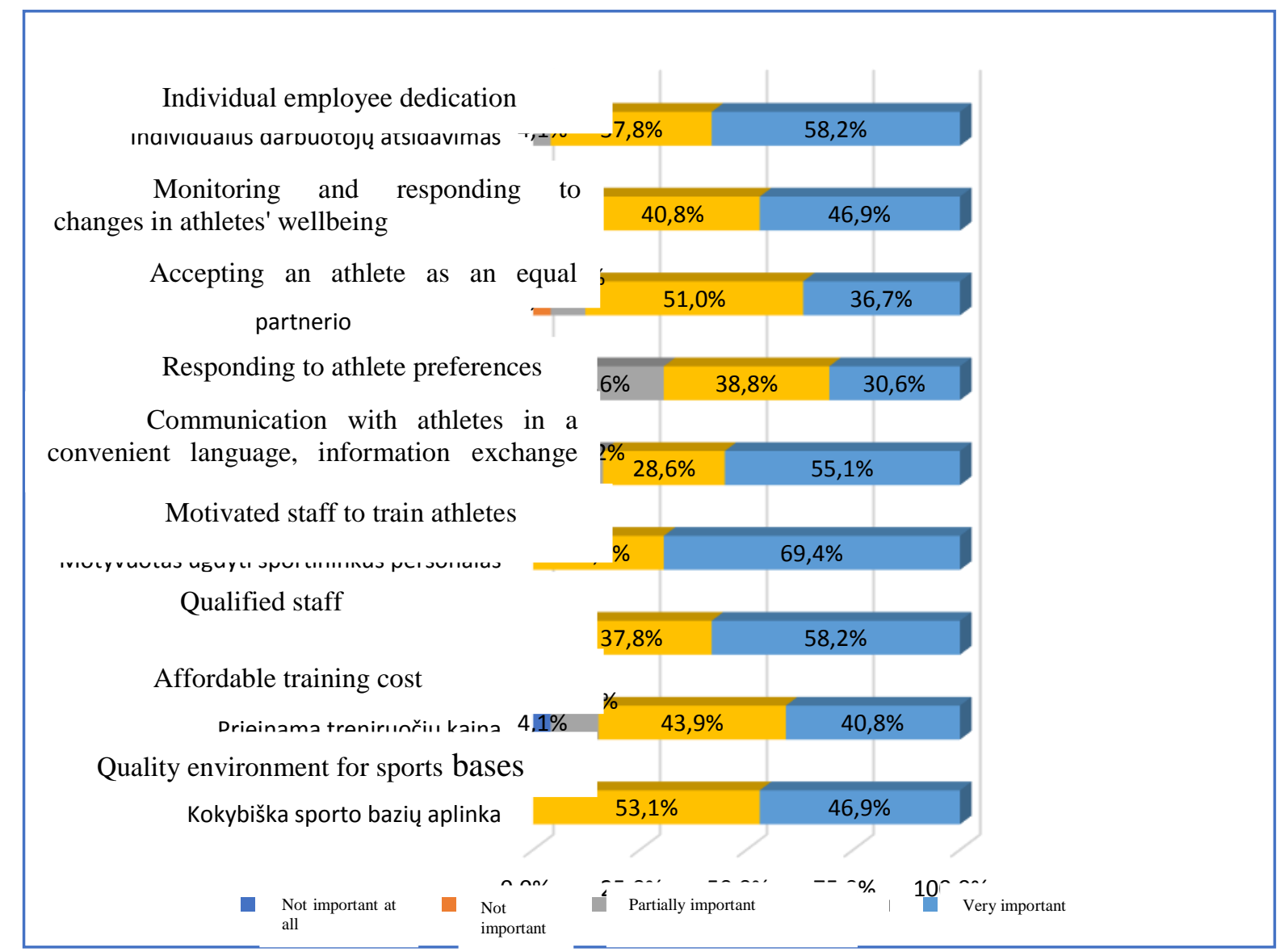


Figure 2. Respondents' attitudes towards important factors of athletic performance development

Summarizing this data and taking an overall look at the results presented in Figure 2, it is seen that all the identified factors of athletic performance development are important, starting with the actions of the staff, qualification, communication with the athletes, ending with the creation of an appropriate environment for sports bases, etc.

During the survey, the respondents also assessed various functions and roles of coaches' professional activities (see Figure 3). The obtained results show that the following are the most valued professional activities of coaches: knowledge of their sport (good - 38.8\%; very good - 46.9\%); athlete support (respectively 27.6\%; $37.8 \%$ ), raising sport education aims $(39.8 \% ; 39.8 \%)$, and provision of "coach-athlete" educational interaction $(55.1 \% ; 26.5 \%)$, creation of educational/self-educational environment and motivational climate $(57.1 \%$; 15.3\%). Promotion of psychological stability, selfconfidence is less valued $(23.5 \%$ rated it moderate, $11.2 \%$ very bad, $4.1 \%$ poor). Approximately one in three respondents rated choice in leadership style $(28.6 \%)$, promotion of tolerance, patience $(27.6 \%)$, organization of educational process $(27.6 \%)$ as moderate.

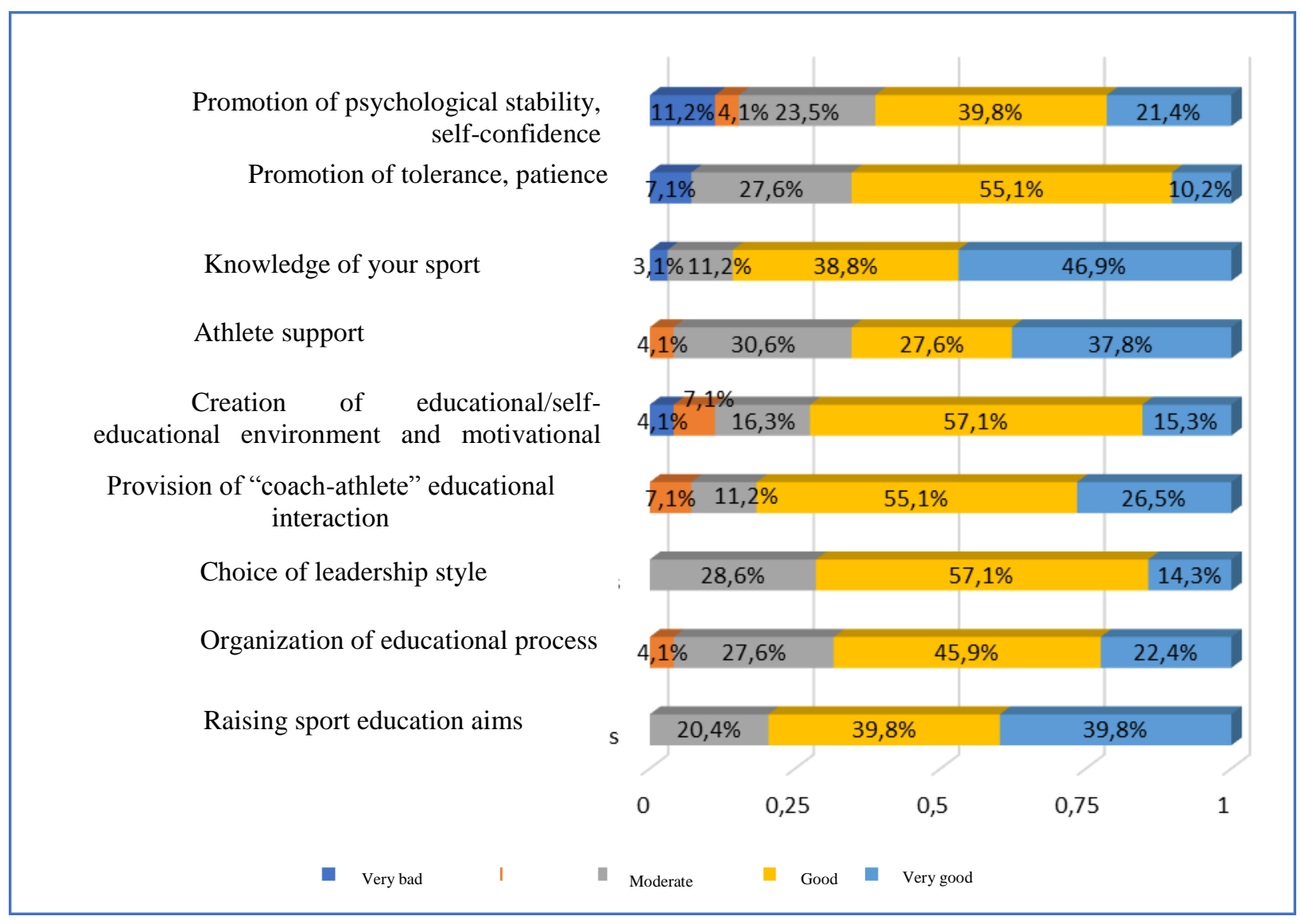

Factors for the preparation of high master athletes in the context of sports organization staff competences 
Figure 3. Assessment of various functions and roles of coaches' professional activities

Consequently, not all roles and functions of coaches' professional activities are rated positively by respondents. Therefore, the roles of promotion of psychological stability, self-confidence, tolerance, patience that were rated poorly, as well as activities of organization of educational process could be improved.

During the survey, the respondents were asked to rate the professional and personal qualities of coaches, which, as demonstrated by the theoretical part of the work, are also relevant to athlete performance (see Figure 4).

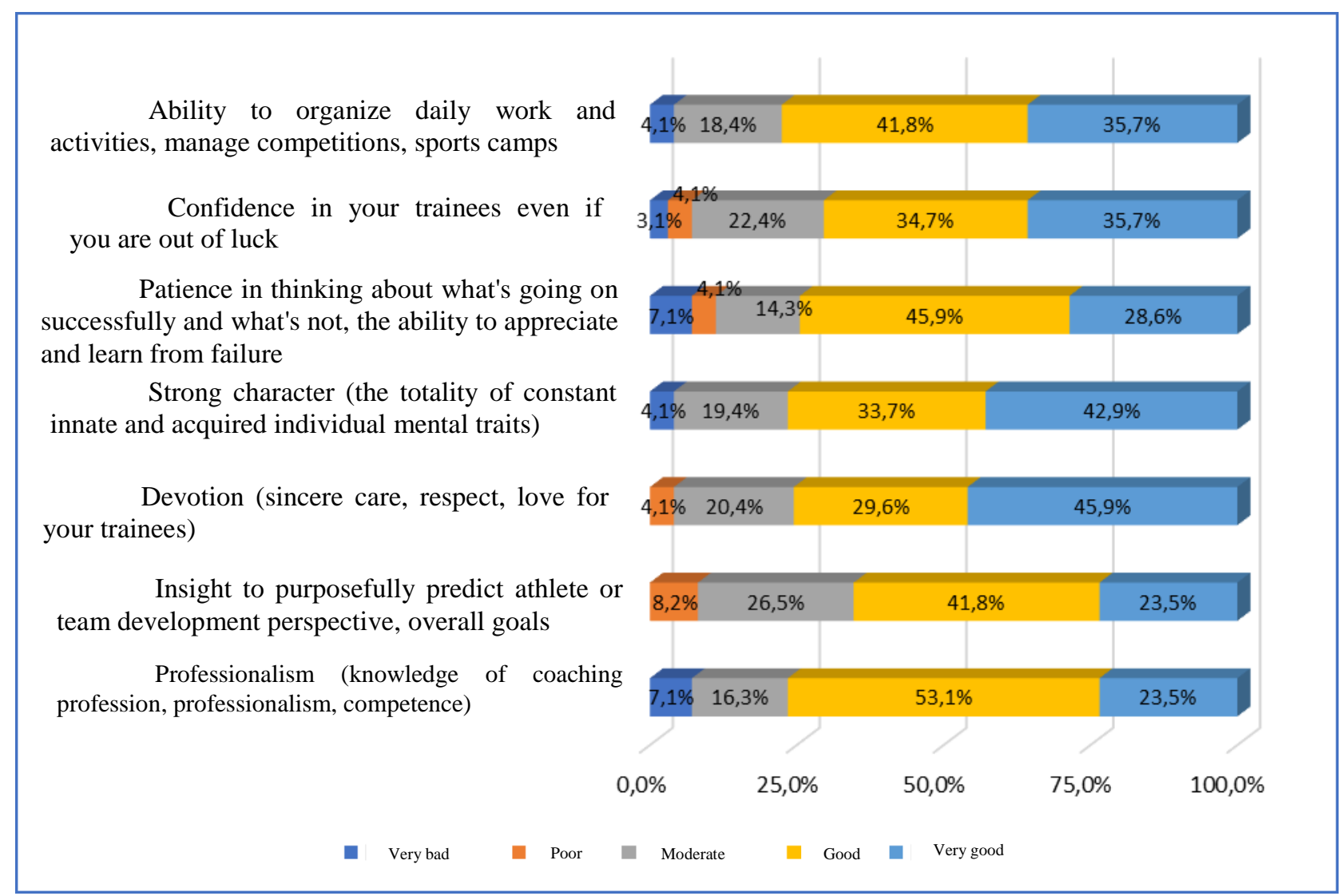

Figure 4. Assessing the professional and personal qualities of coaches

The obtained results showed that almost half of the respondents evaluate the strong character of the coaches $(42.9 \%)$, devotion (i.e. sincere care, respect, etc.) (45.9\%) as very good.

Well over half of the respondents assess the professionalism of the coach (i.e. knowledge of the coaching profession, competence) (53.1\%), patience, thinking over and assessing abilities $(45.9 \%)$, insight (i.e. actions to purposefully predict athlete or team development perspective, overall goals) $(41.8 \%)$ as good. Approximately one fifth of the respondents assess a coach's confidence in their trainees $(22.4 \%)$, ability to organize daily work and 
and confidence in athletes was sports camps (18.4\%) as moderate.

Thus, most of the respondents assessed the coaches' strong character and dedication to work as very good, while the ability to organize activities assessed as moderate.

The survey also revealed how respondents assess the adequacy of the competences needed by coaches to train high-performance athletes (see Figure 5).

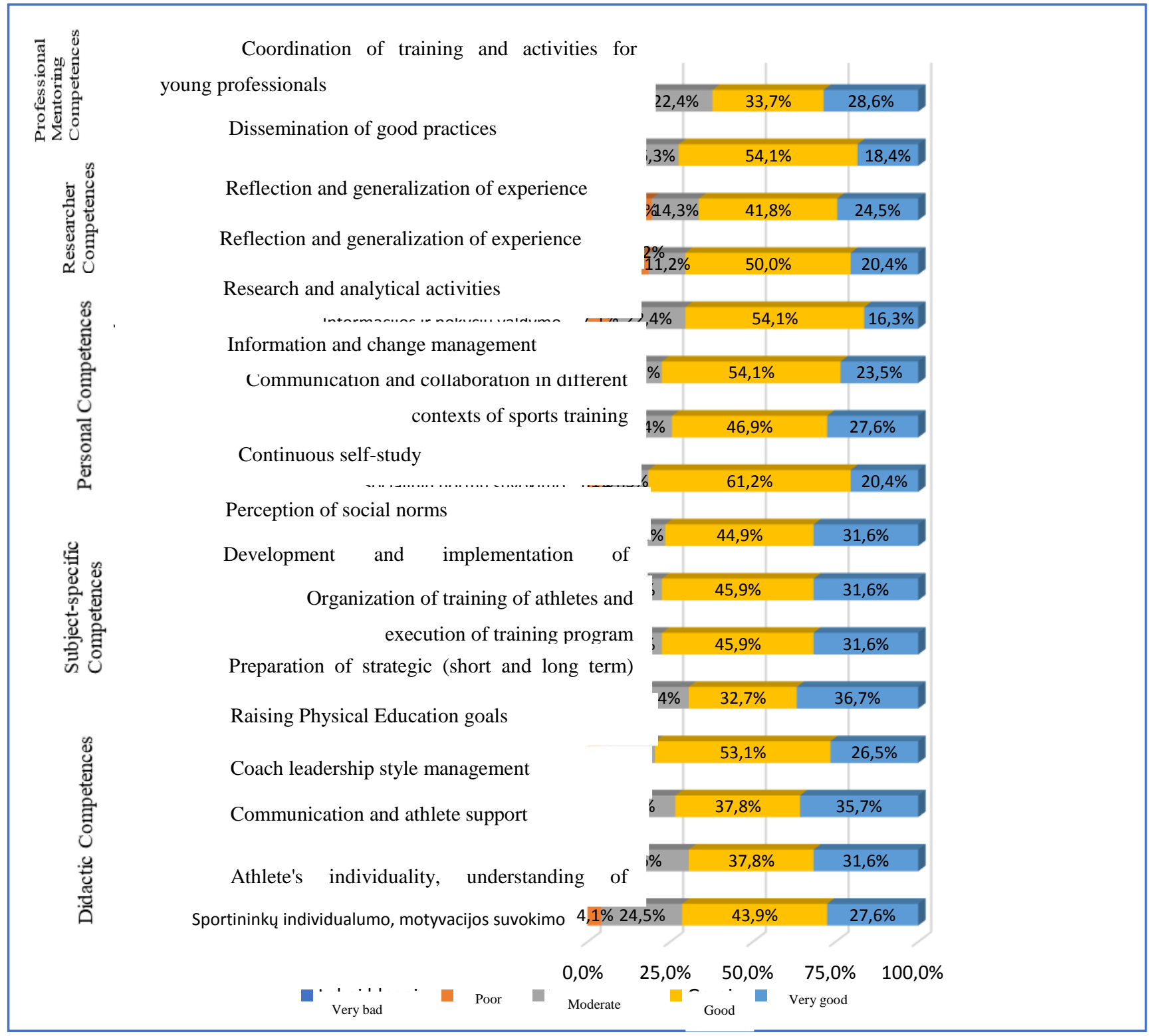

Figure 5. Respondents' attitudes towards the adequacy of the competences needed by coaches in training high performance athletes

The obtained data showed that a competences (especially raising lot of respondents assess didactic physical education goals - 36.7\%) as competences (especially very good. Most people assess communication and athlete support - personal competences (especially $35.7 \%)$ and subject-specific perception of social norms - 61.2\%;

Factors for the preparation of high master athletes in the context of sports organization staff competences 
communication and collaboration in different contexts of sports training $54.1 \%$;) as good, as well as researcher competences (especially information and change management $54.1 \%$, the dissemination of good practices - $54.1 \%$ ), professional mentoring competence (i.e. coordination of training and activities for young professionals - 33.7\%).

All in all, it can be concluded that the majority of respondents are in favor of matching the didactic and subject-specific competences required by coaches in training high performance athletes.

\section{CONCLUSIONS}

Responses to sport-specific activities have shown that respondents value the achievement of high performance athletes, their involvement in the sports market, the purposeful implementation of sports organization functionality through a team of employees and the achievement of goals.

Retention of existing athletes and attraction of new ones, financial resources, involvement of sponsors are less valued.

According to the majority of respondents, the most important factors for athletes' performance are: a high quality environment for sports facilities; qualified and motivated staff to train athletes; individual employee dedication.

However, many respondents value on average the motivation of staff to develop athletes and the quality of the environment in their sports facilities. Not all are satisfied with observing and responding to changes in athletes' well-being, accepting an athlete as an equal partner, and individual dedication of staff.

The majority of respondents believe that athletes' performance depends mainly on their job satisfaction, opportunities for improvement and reward. Respondents most appreciate the following professional activities of coaches: knowledge of their sport; athlete support; goal setting for sports; providing coach-athlete educational interaction; creating an environment and motivational climate.

The results of the coaches 'professional and personal qualities showed that most of the respondents rated the coaches' strong character and dedication to work, and on average, their ability to organize activities and confidence in athletes. It turned out that the longer the respondents' training time in a sports organization, the more favorable they are to the professionalism of the coaches. However, respondents with the shortest training in a sports organization prefer coaching insight and dedication to work, unlike longer training.

Athletes who have shorter training time in the organization have been found to be more supported by coaches and receive more attention. It appears that many respondents are in favor of matching the didactic and subject competencies required by coaches to train high performance athletes.

During the research, the directions of improvement of sports organization personnel management in order to 
increase the performance of athletes were determined, which are related both to the functions of the coaches, their competence and the personnel management of the sports organization.
Specific recommendations were made to managers and coaches of sports organizations, taking into account the research findings and identified weaknesses in the organization's personnel management.

\section{Список использованных источников}

1. Adaškevičienè, E., 2014. Mokinių fizinio aktyvumo didinimo galimybès sveikatos požiūriu: kūno kultūros mokytojų nuomonè. Tiltai, Nr. 1, 49-66.

2. Anastasovski, I., Aleksovska, L., Naumovski, M. et al., 2017. New challenge - gender structure in the process of management in sports and sports organization impact from legal and economic aspects. Research in Physical Education, Sport and Health, 6 (2), 9-13.

3. Camire, M., 2015. Reconciling competition and positive youth development in sport. Dans Staps, No 3 (109), 25-39.

4. Camy, J., Robinson, L., 2017. Olimpinių sporto organizacijų vadyba. JAV: United Graphics.

5. Coakley, J., 2011. Youth sports: What counts as positive youth development? Journal of Sport and Social Issues, No 35(3), 306-324.

6. Česnavičienè, J., Gudžinskienė, V., 2014. Mokytojų, kaip sveikatos ugdytojų, vaidmuo ir jų patirtys igyvendinant integruotą sveikatos ugdymą. Andragogika, T. 1(5), $27-$ 43.

7. Dimopoulou, S., Avgerinou, V., Samioti, S. E., et al., 2018. The Importance of Total Quality Management and Business Excellence in Sports Organizations - A Case Study in Olympic Athletic Center. Spiros Louis, Choregia, 14(2), 49-54.

8. Dilys, M., 2015. Sporto organizacijų ir rėmejų darnaus bendradarbiavimo vadybiniai veiksniai: daktaro disertacija. Socialiniai mokslai, vadyba (03S). Vilnius: VU.

9. Iancu, D., Robescu, O., Istrate, C. et al., 2016. Management of Sports Organizations: Concepts, Skills, Knowledge. Valahian Journal of Economic Studies. 7 (21-3), 75-82.

10. Fahlen, J., Stenling, C., 2019. (Re)conceptualing institutional change in sport management contexts: the unintended consequences of sport organizacions everyday organizacional life. European Sport Management Quarterly, 19(2), 265-285.

11. Hallmann, K., Giel, T., 2018. eSports - Competitive sports or recreational activity? Sport Management Review, 21, 14-20.

12. Juodeikaitè, M., Fominienè, A., 2016. Žmogiškujų išteklių valdymo procesų pokyčių vertinimas: teorinis ir praktinis aspektas. Informacijos mokslai, Nr. 74, 25-37.

13. Lebedžinskas, J., Bobrova, L., Grabauskas A., 2016. Jaunujų futbolininkų asmeninès kompetencijos raiška. Studijos šiuolaikinejje visuomenejje: mokslo darbai, Nr. 7(1), 279-292.

14. LR sporto įstatymas, 2018. TAR 2018-10-31, i. k. 2018-17451.

15. Molcut, A., Elvira, V., Flavius, N., 2015. Sports organizations management improvement: a survey analysis. Annals of Faculty of Economics, 1(1). 1019-1028.

16. Mikalauskas R., Šimkus A., Alekrinskis A., ir kt., 2015. Teikiamų paslaugų kokybès vertinimo aspektai sporto organizacijoje. Mokslas ir praktika. Aktualijos ir perspektyvos: tarptautinè mokslinè konferencija, 2015 balandžio 16-17 d. 47

17. Martin, E. M., Ewing, M. E., Gould, D., 2014. Social agents' influence on selfperceived good and bad behavior of American youth involved in sport: Developmental level, gender, and competitive level effects. The Sport Psychologist, No 28. 111-123.

Factors for the preparation of high master athletes in the context of sports organization staff competences 
18. Petronel, M., Florentina, M., 2013. Sports Organization Management: Between Constraints and Objectives. Procedia - Social and Behavioral Sciences, 81.95-99. l-kla.

19. Rupšienè, L., 2007. Kokybinio tyrimo duomenų rinkimo metodologija. Klaipėda: $K U$

20. Strazdienė, N., Adaškevičienè, E., 2011. Mokytojų pilietinè pozicija ir dalykinè kompetencija ugdant vaikų sveikatą. Tiltai, 3, 169-180.

21. Sabaliauskas, S., 2017. Trenerių, rengiančių didelio meistriškumo sportininkus, kompetencijų sisteminė apžvalga. Sporto mokslas, 1(87), 3-9.

22. Spaulding, D.T., Smith, G.M., 2010. Intructional Coaches and the Instructional Leadership Team. Galifornia: Corwin.

23. Siegfrieda, N., Schlesingerb, T., Baylec E. et al., 2015. Professionalisation of sport federations - a multi-level framework for analysing forms, causes and consequences. European Sport Management Quarterly, Vol. 15, No. 4, 407-433.

24. Sterkowicz, S., Garcia, J.M., Lerma, F.S., 2007. The importance of judo trainers' professional activities. Archives of Budo, Vol. 3, 57-61.

25. Sobreiro, P.A., Santos-Rocha, R., Claudino, R. et al., 2018. Approach to management by processes in a sports department of a local government organization. Motricidade, 14 (2), 79-94.

26. Schmidt, J., 2017. Professionalism in Management and Performance in Sports Organizations, pp. 87-99. [žiūrèta 2019 m. gruodžio 13 d.]. Prieiga internetu: https://www.researchgate.net/publication/324765448_Professionalism_in_Management_and_ Performance_in_Sports_Organizations

27. Taylor, J., 2009. Sports: What Motivates Athletes? How can athletes maximize their motivation? Psichology today, [žiūrèta $2020 \mathrm{~m}$. sausio $3 \mathrm{~d}$.]. Prieiga internetu: https://www.psychologytoday.com/us/blog/the-power-prime/200910/sports-what-motivatesathletes

28. Valackienè, A., 2004. Sociologinis tyrimas. Kaunas: Technologija.

29.Žilinskienè, N., 2008. Šuolininkų i aukšti sportinio rengimo skirtingais etapais optimizavimas: daktaro disertacija. Socialiniai mokslai, edukologija (07 S). Fizinis lavinimas, judesių mokymas, sportas (S273). Vilnius: VPU l-kla.

30. Žydžiūnaitè, V., Sabaliauskas, S., 2017. Kokybiniai tyrimai. Principai ir metodai. Kaunas: Vaga.

\section{REFERENSES}

1. Adaškevičienè, E., 2014. Mokinių fizinio aktyvumo didinimo galimybès sveikatos požiūriu: kūno kultūros mokytojų nuomonè. Tiltai, 1, 49-66.

2. Anastasovski, I., Aleksovska, L., Naumovski, M. et al., 2017. New challenge - gender structure in the process of management in sports and sports organization impact from legal and economic aspects. Research in Physical Education, Sport and Health, 6 (2), 9-13.

3. Camire, M, 2015. Reconciling competition and positive youth development in sport. Dans Staps, No 3 (109), 25-39.

4. Camy, J., Robinson, L., 2017. Olimpinių sporto organizacijų vadyba. JAV: United Graphics.

5. Coakley, J., 2011. Youth sports: What counts as positive youth development? Journal of Sport and Social. Issues, 35(3). 306-324.

6. Česnavičienè, J., Gudžinskienè, V., 2014. Mokytojų, kaip sveikatos ugdytojų, vaidmuo ir jų patirtys iggyvendinant integruotą sveikatos ugdymą. Andragogika, T. 1(5).27-43.

7. Dimopoulou, S., Avgerinou, V., Samioti, S. E., et al., 2018. The Importance of Total Quality Management and Business Excellence in Sports Organizations - A Case Study in Olympic Athletic Center. Spiros Louis, Choregia, 14 (2). 49-54. 
8. Dilys, M., 2015. Sporto organizacijų ir rèmėjų darnaus bendradarbiavimo vadybiniai veiksniai: daktaro disertacija. Socialiniai mokslai, vadyba (03S). Vilnius: $V U$.

9. Iancu, D., Robescu, O., Istrate, C. et al., 2016. Management of Sports Organizations: Concepts, Skills, Knowledge. Valahian Journal of Economic Studies. 7 (21-3).75-82.

10. Fahlen, J., Stenling, C., 2019. (Re)conceptualing institutional change in sport management contexts: the unintended consequences of sport organizacions everyday organizacional life. European Sport Management Quarterly, 19 (2). 265-285.

11. Hallmann, K., Giel, T., 2018. eSports - Competitive sports or recreational activity? Sport Management Review, 21. 14-20.

12. Juodeikaite, M., Fominienè, A., 2016. Žmogiškujų išteklių valdymo procesų pokyčių vertinimas: teorinis ir praktinis aspektas. Informacijos mokslai, 74.2 25-37.

13. Lebedžinskas, J., Bobrova, L., Grabauskas A., 2016. Jaunųų futbolininkų asmeninès kompetencijos raiška. Studijos šiuolaikinèje visuomenëje: mokslo darbai, Nr. 7(1).279-292.

14. LR sporto įstatymas. TAR 2018-10-31, i. k. 2018-17451.

15. Molcut, A., Elvira, V., Flavius, N., 2015. Sports organizations management improvement: a survey analysis. Annals of Faculty of Economics, 1(1). 1019-1028.

16. Mikalauskas R., Šimkus A., Alekrinskis A., ir kt., 2015. Teikiamų paslaugų kokybès vertinimo aspektai sporto organizacijoje. Mokslas ir praktika. Aktualijos ir perspektyvos: tarptautine moksline konferencija, 2015 balandžio 16-17 d. 47.

17. Martin, E. M., Ewing, M. E., Gould, D., 2014. Social agents' influence on selfperceived good and bad behavior of American youth involved in sport: Developmental level, gender, and competitive level effects. The Sport Psychologist, No 28.111-123.

18. Petronel, M., Florentina, M. (2013). Sports Organization Management: Between Constraints and Objectives. Procedia - Social and Behavioral Sciences, 81.95-99. l-kla.

19. Rupšienè, L., 2007. Kokybinio tyrimo duomenų rinkimo metodologija. Klaipėda: $K U$

20. Strazdienè, N., Adaškevičienè, E., 2011. Mokytojų pilietinė pozicija ir dalykinė kompetencija ugdant vaikų sveikatą. Tiltai, 3.169-180.

21. Sabaliauskas, S., 2017. Trenerių, rengiančių didelio meistriškumo sportininkus, kompetencijų sisteminè apžvalga. Sporto mokslas, 1(87).3-9.

22. Spaulding, D.T., Smith, G.M., 2010. Intructional Coaches and the Instructional Leadership Team. Galifornia: Corwin.

23. Siegfrieda, N., Schlesingerb, T., Baylec E. et al., 2015. Professionalisation of sport federations - a multi-level framework for analysing forms, causes and consequences. European Sport Management Quarterly, Vol. 15, 4.407-433.

24. Sterkowicz, S., Garcia, J.M., Lerma, F.S., 2007. The importance of judo trainers' professional activities. Archives of Budo, Vol. 3.57-61.

25. Sobreiro, P.A., Santos-Rocha, R., Claudino, R. et al., 2018. Approach to management by processes in a sports department of a local government organization. Motricidade, 14 (2). 79-94.

26. Schmidt, J., 2017. Professionalism in Management and Performance in Sports Organizations, pp. 87-99. [žiūrèta 2019 m. gruodžio 13 d.]. Prieiga internetu: https://www.researchgate.net/publication/324765448_Professionalism_in_Management_and_ Performance_in_Sports_Organizations

27. Taylor, J., 2009. Sports: What Motivates Athletes? How can athletes maximize their motivation? Psichology today, [žiūrèta $2020 \mathrm{~m}$. sausio $3 \mathrm{~d}$.]. Prieiga internetu: https://www.psychologytoday.com/us/blog/the-power-prime/200910/sports-what-motivatesathletes

28. Valackienè, A., 2004. Sociologinis tyrimas. Kaunas: Technologija.

Factors for the preparation of high master athletes in the context of sports organization staff competences 
29. Žilinskiené, N., 2008. Šuolininkų i aukštį sportinio rengimo skirtingais etapais optimizavimas: daktaro disertacija. Socialiniai mokslai, edukologija (07 S). Fizinis lavinimas, judesių mokymas, sportas (S273). Vilnius: VPU l-kla.

30. Žydžiūnaitè, V., Sabaliauskas, S., 2017. Kokybiniai tyrimai. Principai ir metodai. Kaunas: Vaga.

ШАРУНАС БИЧЮШАС - магистр кафедры менеджмента спорта и туризма, Литовский спортивный университет (Каунас, Литва)

E-mail: s.biciusas@gmail.com, ORCID iD: https://orcid.org/0000-0003-0368-2417

\section{ФАКТОРЫ ПОДГОТОВКИ СПОРТСМЕНОВ ВЫСШЕГО МАСТЕРСТВА В КОНТЕКСТЕ КОМПЕТЕНЦИЙ ПЕРСОНАЛА СПОРТИВНЫХ ОРГАНИЗАЦИЙ}

Аннотация. Для спортивных организаций важно не только сохранить существующих спортсменов, привлечь новых, но и уметь раскрыть свой профессионализм и помочь им достичь хороших результатов. Достижение результатов спортсменов важно в управлении персоналом спортивных организаций. В управлении персоналом включается множество компонентов. Это исследование поднимает следующий проблемный вопрос - что необходимо изменить (улучшить) в управлении персоналом спортивных организаций с целью повышения работоспособности спортсменов?

В научной литературе более подробно рассматриваются особенности управления спортивной организацией [5] и значение улучшения в управлении качества обслуживания) [6] влияние профессионализма в управлении персоналом достигая результатов деятельности спортивных организаций $[8,3,9]$, организационные показатели $[7,4]$, влияние институциональных изменений на деятельность спортивных организаций $[2,3]$, значение электронного спорта в организационном управлении [4], влияние гендерных различий на спортивные организации в управлении [1] и др.

Цель исследования - определить направления совершенствования управления персоналом спортивной организации путем изучения содержания управления персоналом спортивной организации и роли персонала в развитии спортивных результатов.

Задачи исследования: проанализировать роль персонала спортивных организаций в подготовке спортсменов; изучить факторы развития спортивных результатов; определить специфику и содержание управления персоналом спортивной организации с целью выступления спортсмена; определить направления совершенствования управления персоналом спортивных организаций с целью повышения работоспособности спортсменов. Для достижения целей исследования используются следующие методы: анализ и обобщение научной литературы, количественный опрос и статистический анализ.

Выводы. По мнению большинства респондентов, наиболее важными факторами в подготовке спортсменов являются: высокое качество спортивных сооружений; квалифицированный и мотивированный персонал для подготовки спортсменов; индивидуальная преданность персонала. Тем не менее, многие респонденты в среднем оценивают мотивацию персонала к развитию спортсменов и качество спортивных сооружений. Респонденты больше всего ценят следующие виды профессиональной деятельности тренеров: знание своего вида спорта; поддержка спортсмена; постановка целей в спорте; обеспечение тренерско-атлетического образовательного взаимодействия; создание среды и мотивационного климата.

Результаты профессиональных и личных качеств тренеров показали, что большинство респондентов оценили сильный характер тренеров и их преданность работе, а также их способность организовывать занятия и уверенность в спортсменах.

(C) Šarūnas Bičiušas, 2019 
Похоже, что многие респонденты выступают за соответствие дидактических и предметных компетенций, которые требуются для подготовки спортсменов с высшего мастерства. В ходе исследования были определены направления совершенствования управления персоналом, которые связаны как с функциями тренеров, их компетенцией с целью повышения работоспособности спортсменов, так и с управлением персонала спортивной организации.

Ключевые слова: спортивные организации, управление персоналом, компетенции, спортсмены

ШАРУНАС БІЧЮШАС - магістр кафедри менеджменту спорту i туризму, Литовський спортивний університет (Каунас, Литва)

E-mail: s.biciusas@gmail.com, ORCID iD: https://orcid.org/0000-0003-0368-2417

\section{ЧИННИКИ ПІДГОТОВКИ СПОРТСМЕНІВ ВИЩОЇ МАЙСТЕРНОСТІ В КОНТЕКСТІ КОМПЕТЕНЦІЙ ПЕРСОНАЛУ СПОРТИВНИХ ОРГАНІЗАЦІЙ}

Анотація. Для спортивних організацій важливо не лише зберегти існуючих спортсменів, залучити нових, але й вміти розкрити свій професіоналізм і допомогти їм досягти добрих результатів. Досягнення результатів спортсменів $\epsilon$ важливим в управлінні персоналом спортивних організацій. В управління персоналом включається безліч компонентів. Це дослідження піднімає наступне проблемне питання - що необхідно змінити (поліпшити) в управлінні персоналом спортивних організацій 3 метою підвищення працездатності спортсменів?

У науковій літературі детальніше розглядаються особливості управління спортивною організацією [5] i значення поліпшення в управлінні якості обслуговування) [6], вплив професіоналізму в управлінні персоналом, що досягає результатів у діяльності спортивних організацій $[8,3,9]$, організаційні показники $[7,4]$, вплив інституційних змін на діяльність спортивних організацій [2, 3], значення електронного спорту в організаційному управлінні [4], вплив гендерних відмінностей на спортивні організації в управлінні [1] та ін.

Мета дослідження - визначити напрями вдосконалення управління персоналом спортивної організації шляхом вивчення вмісту управління персоналом спортивної організації і ролі персоналу у розвитку спортивних результатів.

Завдання дослідження: проаналізувати роль персоналу спортивних організацій в підготовці спортсменів; вивчити чинники розвитку спортивних результатів; визначити специфіку і вміст управління персоналом спортивної організації з метою виступу спортсмена; визначити напрями удосконалення управління персоналом спортивних організацій з метою підвищення працездатності спортсменів. Для досягнення цілей дослідження використовуються наступні методи: аналіз і узагальнення наукової літератури, кількісне опитування і статистичний аналіз.

Висновки. На думку більшості респондентів, найбільш важливими чинниками в підготовці спортсменів $\epsilon$ : висока якість спортивних споруд; кваліфікований i мотивований персонал для підготовки спортсменів; індивідуальна відданість персоналу. Проте, багато респондентів в середньому оцінюють мотивацію персоналу до розвитку спортсменів і якість спортивних споруд. Респонденти більш всього цінують наступні види професійної діяльності тренерів: знання свого виду спорту; підтримка спортсменів; постановка цілей у спорті; забезпечення тренерсько-атлетичної освітньої взаємодії; створення середовища і мотиваційного клімату.

Результати професійних і особистих якостей тренерів показали, що більшість респондентів оцінили сильний характер тренерів та їх відданість роботі, а також їх здатність організовувати заняття і упевненість у спортсменах.

Factors for the preparation of high master athletes in the context of sports organization staff competences 
Схоже, що багато респондентів виступають за відповідність дидактичних і наочних компетенцій, які потрібні для підготовки спортсменів з вищої майстерності. В ході дослідження були визначені напрями вдосконалення управління персоналом, які пов'язані як з функціями тренерів, їх компетенцією з метою підвищення працездатності спортсменів, так і з управлінням персоналу спортивної організації.

Ключові слова: спортивні організації, управління персоналом, компетенції, спортсмени

Received date 02.01.2020

Accepted date 15.01.2020

Published date 20.01.2020 